\title{
The Effects of Chronic Renal Failure in Infancy on Growth, Nutritional Status and Body Composition
}

\author{
R.W.A. JONES, ${ }^{(49)}$ S.P. RIGDEN, T.M. BARRATT, AND C. CHANTLER
}

Evelina Children's Department, Guy's Hospital, London, United Kingdom and the Hospital for Sick Children, Great Ormond Street, London, United Kingdom

\begin{abstract}
Summary
Growth, body composition, and nutritional status were assessed in 21 children (age range, $0.3-11.9$ years) with advanced chronic renal failure (CRF, glomerular filtration rate $<20 \mathrm{ml} / \mathrm{min} / 1.73 \mathrm{~m}^{2}$ ), which had presented in the first year of life. Height standard deviation score was $\mathbf{- 2}$ or less in $\mathbf{1 6}$ children. Intracellular water (ICW), an index of body cell mass, was reduced compared to values predicted for height in 14 children studied under 3 years of age IGroup I, mean ICW observed:predicted ratio $(\mathrm{O} / \mathrm{P}) 0.67$, range $0.50-0.93$, but was normal in seven prepubertal children studied between 5-11.9 years of age (Group II, mean ICW O/P 1.01 , range $0.88-1.23, P<0.01$ compared to Group I). Both ICW $O / P$ and weight for height index increased significantly with age throughout childhood $(r=0.79, P<0.001$ and $r=0.62, P<0.05$, respectively). In Group I, height standard deviation score correlated significantly with $\mathrm{ICW} \mathrm{O} / \mathrm{P}$, weight for height index, and serum transferrin. The most growth retarded children had the most marked reduction in body cell mass, were the most wasted, and had the lowest serum transferrin levels. In this group mean serum transferrin was significantly reduced compared to normal, and levels were closely correlated with weight for height index. Repeat estimations of ICW, performed in seven Group I children after an interval of 0.4-0.8 years, showed an increase towards predicted normal in six cases. In Group II, mean weight for height index was normal $(101 \%$, range $90-114 \%)$ and significantly greater than for Group I (mean 86\%, range $70-114 \%, P<0.01$ ), and there was no significant correlation between height standard deviation score and either ICW O/P ratio, weight for height index, or serum transferrin. Thus, abnormalities of body composition and nutritional status could no longer be implicated as important determinants of height deficit. Dietary calorie intakes in all children not receiving calorie supplements, and in many of those receiving supplements, were below recommended intakes for height age in both groups.
\end{abstract}

\section{Speculation}

These results indicate similarities between children with early onset chronic renal failure and those with protein-calorie malnutrition, and suggest the importance of nutritional deficiency and consequent body protein depletion in the early pathogenesis of their growth retardation. The increase in intracellular water values towards normal during infancy, and the finding of normal intracellular water and weight for height in older children, suggest that adaptive mechanisms may have minimised long term disturbances of body composition. Nutritional therapy to promote catch-up growth may only succeed if applied early in childhood before this adaptation has occurred.

As a result of increased survival on regular dialysis or after transplantation, poor growth has become a particularly important problem in the management of children with chronic renal failure (CRF) $(2,9,26,33)$. A deficient intake of nutrients is one important contributory factor (24) which, compounded by hormonal and metabolic abnormalities, leads to a state of body protein depletion. The similarities between children with CRF and those with protein-calorie malnutrition (PCM) have been previously noted $(9,23)$. Evidence of protein depletion in CRF includes reduction in alkaline soluble protein on muscle biopsy (17), decreased whole body protein and albumin turnover $(4,16)$, decreased plasma and intracellular concentrations of certain essential amino acids $(7,27)$, decreased levels of short half-life serum proteins $(27,47)$, an increased protein catabolic response to fasting (22), reduced total body nitrogen (34), and reduced body cell mass as estimated by measurement of ICW $(6,14,15,19)$ and total body potassium (TBK) $(39,43)$. In infancy, when calorie and protein requirements per $\mathrm{kg}$ and rates of body growth and nitrogen accretion are greatest, the impact of uraemia is likely to be particularly severe. Studies confirm that children whose CRF dates from early life are indeed the most growth retarded $(2,20$, 33) as a result not of poor growth throughout childhood, but rather due to early loss of growth potential $(2,33)$. Whilst abnormalities of body composition and metabolism in older children and adults with CRF have been extensively investigated, no studies on the effects of uraemia in infancy are available. We have therefore examined, in a group of infants and children whose CRF had presented in the first year of life, both the early and later effects of their uraemia on growth, nutrition and body composition with particular reference to body protein status.

\section{PATIENTS}

Twenty-one children who had advanced $\mathrm{CRF}$ with a glomerular filtration rate (GFR) less than $20 \mathrm{ml} / \mathrm{min} / 1.73 \mathrm{~m}^{2}$, and in whom there was adequate documentation of their presentation in the first year of life with uraemia, were studied. Fifteen cases presented below the age of 1 month. All but one child was shown by intravenous urography or cystourethrography to have congenital renal hypoplasia with or without ureteric reflux and urethral valves. Abdominal ultrasound and nuclear imaging provided confirmatory diagnostic information in some children. In case 13, the only girl, oligomeganephronia was shown by percutaneous renal biopsy. Clinical data are shown in Table 1. At the time of study they all had stable renal function and were clinically well. None were oedematous. Many had previously undergone surgical procedures for the relief of ureteric reflux or urinary tract obstruction, but were not studied in the postoperative period. In order to compare the early and later effects of their uraemia on growth, nutrition and body composition, cases were divided into those studied early in life during the period of maximum growth velocity for normal children (Group I, 14 children under 3 years of age), and those studied after this time but before the onset of puberty (Group II, 7 children 5-11.9 years of age). At the time of initial study both groups of children ate a free diet supplemented in some cases by a calorie supplement in the form of glucose polymer (Caloreen, Roussel Labs Ltd., London, U.K.), vegetable oil (Prosparol, Duncan Flockhart Ltd., London, U.K.), or double cream. 
Table 1. Clinical data

\begin{tabular}{|c|c|c|c|c|c|}
\hline \multirow{2}{*}{ Case } & \multirow{2}{*}{ Diagnosis } & \multirow{2}{*}{ Birthweight centile } & \multirow{2}{*}{$\begin{array}{c}\text { Mode of presentation and } \\
\text { age }\end{array}$} & \multicolumn{2}{|c|}{ Plasma creatinine $\mu$ mole/litre } \\
\hline & & & & At presentation & One month later \\
\hline 1. & $\mathrm{CRH}^{1}$ & $\mathrm{NA}^{6}$ & vomiting -3 weeks & 370 & 406 \\
\hline 2. & $\mathrm{CRH} / \mathrm{UV}^{2}$ & NA & palpable bladder -2 days & 356 & 332 \\
\hline 3. & $\mathrm{CRH}$ & $3-10$ & $\mathrm{ftt}-1$ month ${ }^{4}$ & 277 & 227 \\
\hline 4. & $\mathrm{CRH}$ & $75-90$ & palpable kidneys -3 days & 343 & 197 \\
\hline 5. & $\mathrm{CRH} / \mathrm{UV}$ & NA & antenatal ultrasound & 208 & 169 \\
\hline 6. & $\mathrm{CRH}$ & $25-50$ & $\mathrm{ftt}-7$ months & 243 & 208 \\
\hline 7. & $\mathrm{CRH}$ & $50-75$ & uti-6 months ${ }^{5}$ & 213 & 210 \\
\hline 8. & $\mathrm{CRH}$ & $3-10$ & uti-6 weeks & 152 & 175 \\
\hline 9. & $\mathrm{CRH} / \mathrm{UV}$ & NA & $\mathrm{ftt}-9$ months & 311 & 174 \\
\hline 10. & CRH/UV & $50-75$ & palpable bladder -4 days & 303 & 274 \\
\hline 11. & $\mathrm{CRH} / \mathrm{UV}$ & $25-50$ & palpable bladder - 16 days & 505 & 387 \\
\hline 12. & $\mathrm{CRH}$ & $10-25$ & uti-4 weeks & 257 & 228 \\
\hline 13. & $\mathrm{OLIGO}^{3}$ & $50-75$ & $\mathrm{ftt}-3$ months & u $16^{7}$ & 104 \\
\hline 14. & CRH & $\mathrm{NA}$ & $\mathrm{ftt}-2$ weeks & 340 & 306 \\
\hline 15. & $\mathrm{CRH}$ & $3-10$ & vomiting -10 days & u 26 & 270 \\
\hline 16. & $\mathrm{CRH}$ & $25-50$ & $\mathrm{ftt}-2$ weeks & 224 & 202 \\
\hline 17. & $\mathrm{CRH} / \mathrm{UV}$ & $10-25$ & $\mathrm{ftt} / \mathrm{uti}-2$ weeks & 301 & 309 \\
\hline 18. & CRH & $3-10$ & vomiting - 10 days & 160 & 160 \\
\hline 19. & $\mathrm{CRH}$ & $25-50$ & vomiting -2 weeks & u 18 & 212 \\
\hline 20. & $\mathrm{CRH}$ & $10-25$ & $\mathrm{ftt}-4$ weeks & 154 & u 19 \\
\hline 21. & $\mathrm{CRH}$ & $25-50$ & $\mathrm{ftt}-2$ months & u 18 & u 16 \\
\hline
\end{tabular}

${ }^{1} \mathrm{CRH}$, congenital renal hypoplasia.

${ }^{2} \mathrm{UV}$, urethral valves.

${ }^{3}$ OLIGO, oligomeganophronia.

${ }^{4} \mathrm{ftt}$, failure to thrive.

${ }^{5}$ uti, urinary tract infection.

${ }_{7}^{6} \mathrm{NA}$, not available.

${ }^{7} \mathrm{u}$, plasma urea mmole/litre (plasma creatinine not available).

Aluminum hydroxide was prescribed in varying amounts to prevent hyperphosphataemia. All the children received sodium bicarbonate for metabolic acidosis and/or sodium chloride for renal salt wasting, and vitamin D (dihydrotachysterol or 1-alpha-hydroxycholecalciferol) in view of active or previous renal osteodystrophy.

The investigations described in this study were approved by the Ethical Committees of Guy's Hospital Medical School and the Hospital for Sick Children, Great Ormond Street, and informed parental consent was obtained in each case.

\section{METHODS}

Growth and nutritional status. Birthweight centiles for gestational age were calculated from the data of Thomson et al. (41), although this was not possible for children of Asian parenthood (cases 1, 2, 5,9 , and 14). Supine length or standing height was measured using a Harpenden stadiometer; height deficit was expressed as the number of standard deviations below the mean for normal children of the same age calculated from the data of Tanner and Whitehouse (42). Weight was expressed as \% of the 50th centile weight for normal children (42) of the same height (weight for height index). GFR was measured from the slope clearance of intravenously administered $\left[{ }^{51} \mathrm{Cr}\right]$-EDTA (Radiochemical Centre, Amersham, U.K.) (8). In one infant GFR was calculated from body length and plasma creatinine (40). Plasma urea was measured by automatic analyser (Vickers M300), plasma creatinine by the kinetic Jaffe reaction. Serum transferrin was measured by radial immunodiffusion using a commercially available kit (ICL Scientific, Fountain Valley, U.S.A.), the normal range for which is $200-400 \mathrm{mg} / \mathrm{dl}$. In an unmatched control group of infants and children studied by this method the mean value was $296 \pm 69$ S.D. $\mathrm{mg} / \mathrm{dl}$ for children under 3 years of age $(n=8)$, and $259 \pm$ 29 S.D. mg/dl for children 3-12 years of age $(n=14)$.

Body composition. Total body water (TBW) was estimated from the volume of distribution of tritium, plasma being sampled $4 \mathrm{~h}$ after the intravenous injection of $1.5-3 \mu \mathrm{C} / \mathrm{kg}$ body weight of tritiated water (Radiochemical Centre, Amersham, U.K.). After plasma water extraction by vacuum distillation over acetone and dry ice (37), tritium activity was assayed using an LKB Walloc 81000 liquid scintillation counter (29). Extracellular volume (ECV) was estimated from the volume of distribution of sodium bromide $4 \mathrm{~h}$ after the intravenous injection of $0.4 \mathrm{mmole} / \mathrm{kg}$ body weight. Syringes were weighed before and after injection to confirm the exact quantities of tritium and bromide given. Plasma bromide was assayed by excitation fluorimetry (25) using a $\mathrm{Nu}$ clear Data 100 multi-channel analyser with a cadmium source, correction factors being applied for the water content of plasma (0.93), for Donnan equilibrium (0.95), and for the intracellular distribution of $10 \%$ of administered sodium bromide (13). ICW was calculated as TBW minus ECV. No correction for urinary losses of tritium or bromide during the 4-h equilibration period were made because body composition studies in 17 children with CRF (including 10 of those in the present study) in whom urine collections were available, showed that the error incurred by this omission (which results in an overestimate of ICW) was less than $5 \%$ in all cases. Further details of body composition methodology have been described previously (19). Because, for ethical reasons, we were unable to study a matched control group of normal children, results for each child in the study group were compared with values predicted for normal children of the same height. These were calculated from multiple regression equations obtained from studies of body composition in normal children using similar methodology $(12,13,35)$. The following formulae were used:

$$
\begin{aligned}
\text { TBW }= & 0.148 \mathrm{ht}-4.874(\text { Group I) } \\
\text { TBW }= & 0.181 \mathrm{ht}-7.524(\text { Group II }) \\
\text { ICW }= & 3.0705-0.0674 \mathrm{ht} \\
& +0.0000098 \mathrm{ht}^{2} \text { (both groups) }
\end{aligned}
$$

Predicted ECV was calculated from predicted TBW minus pre- 
dicted ICW for both groups. Results for TBW, ECV and ICW were expressed in litres, as a \% of body weight, and as a ratio of the observed to predicted values $(\mathrm{O} / \mathrm{P}$ ratio).

Dietary data. Dietary intakes in 18 children before initial study, and in five group I children between studies, were assessed from 3 -day prospective records compiled by the mothers at home, the mean being calculated from two or more such records. Calorie and protein intakes were calculated from standard tables of food composition (31). Calorie intake was expressed as a \% of RDA (18), and protein intake as a \% of MRP (18), both in relation to the height age of the child. Height age was defined as the age at which the 50th height centile for normal children corresponded to the patient's height.

Statistics. Comparison of the means of paired and unpaired data was by means of the Wilcoxon rank sum tests for nonparametric data. Correlations were calculated by means of least squares linear regression. The 0.05 level of probability was used as the criterion of significance.

\section{RESULTS}

Growth and nutritional status. The distribution of birthweight centiles (Table 1) did not differ significantly from the normal. Length measurements at birth were not available. The most frequent clinical presentation was failure to thrive, nine children presenting in this way. The degree of renal insufficiency at presentation and 1 month later, as indicated by plasma creatinine or urea levels, was comparable in both groups (Table 1). Heights in relation to normal centiles at the time of initial study are shown in Figure 1. Mean height standard deviation score (HSDS) for the 21 children was $-2.98 ; 16$ had values of -2 or less, and in Group Il all except one child had values of -3 or less (Table 2). Mean HSDS for Groups I and II were not significantly different. Most children in Group I were underweight for height, 10 having values

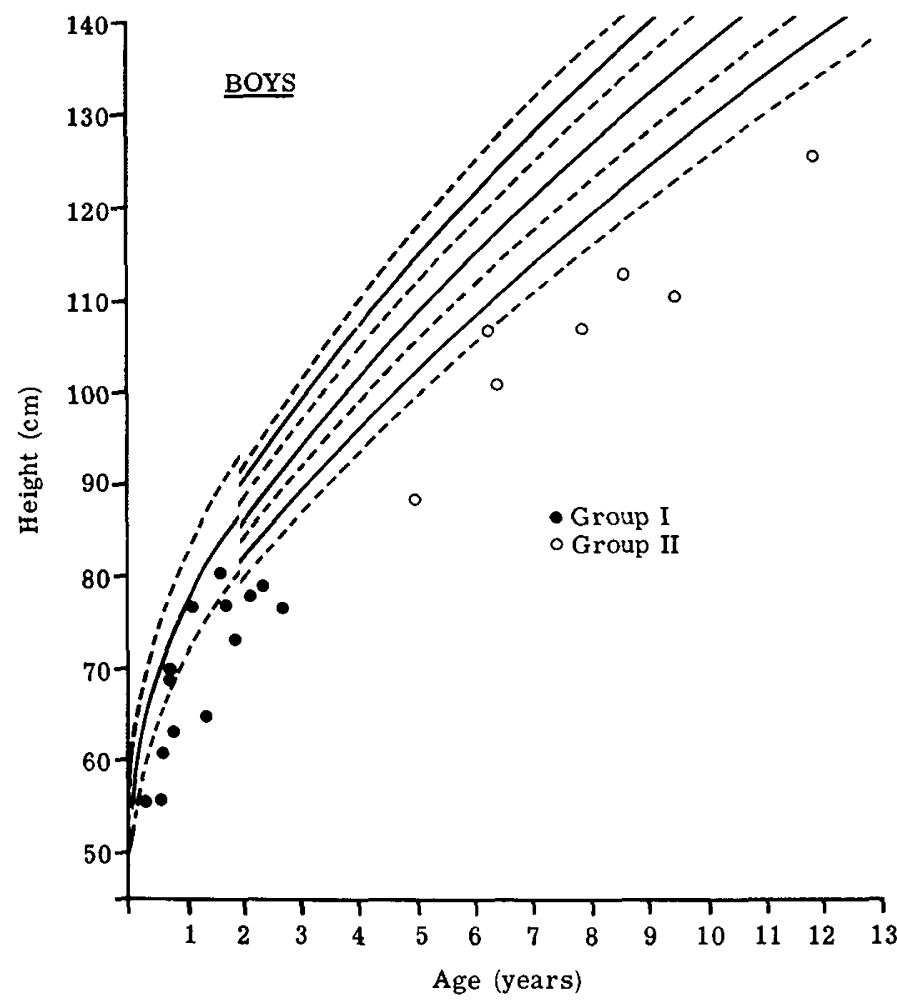

Fig. 1. Heights at initial study plotted on a Tanner (42) centile chart in relation to chronological age. The only female (age 2.3 years) is also shown, plotted in an appropriate position in relation to normal centile lines for girls.

Table 2. Clinical data at time of initial study

\begin{tabular}{|c|c|c|c|c|c|c|c|}
\hline Case & $\begin{array}{l}\text { Age at } \\
\text { study }\end{array}$ & $\begin{array}{l}\text { Height standard de- } \\
\text { viation score chrono- } \\
\text { logic age }\end{array}$ & $\begin{array}{l}\text { Weight for } \\
\text { height index }\end{array}$ & $\begin{array}{c}\text { Glomerular filtration } \\
\text { rate }(\mathrm{ml} / \mathrm{min} / 1.73 \\
\left.\mathrm{m}^{2}\right)\end{array}$ & $\begin{array}{l}\text { Plasma creatinine } \\
\text { ( } \mu \text { mole/litre })\end{array}$ & $\begin{array}{l}\text { Plasma urea } \\
\text { (mmole/litre) }\end{array}$ & $\begin{array}{l}\text { Serum trans- } \\
\text { ferrin }(\mathrm{mg} / \mathrm{dl})\end{array}$ \\
\hline \multicolumn{8}{|l|}{ Group I } \\
\hline 1. & 0.3 & -2.27 & 85 & 3 & 431 & 10 & 225 \\
\hline 2. & 0.5 & -5.4 & 80 & $10^{1}$ & 260 & 15 & 213 \\
\hline 3. & 0.6 & -3.75 & 75 & 9 & 245 & 26 & 107 \\
\hline 4. & 0.7 & -1.3 & 93 & 17 & 115 & 15 & 270 \\
\hline 5. & 0.7 & -1.1 & 84 & 19 & 140 & 9 & 300 \\
\hline 6. & 0.8 & -3.85 & 81 & 5 & 235 & 10 & 145 \\
\hline 7. & 1.1 & -0.41 & 114 & 7 & 330 & 25 & 300 \\
\hline 8. & 1.3 & -5.2 & 83 & 16 & 103 & 13 & 205 \\
\hline 9. & 1.6 & -1.0 & 85 & 18 & 130 & 17 & 235 \\
\hline 10. & 1.7 & -2.0 & 91 & 15 & 260 & 22 & 250 \\
\hline 11. & 1.9 & -4.0 & 84 & 7 & 358 & 11 & 145 \\
\hline 12 & 2.1 & -2.55 & 91 & 9 & 164 & 12 & 315 \\
\hline 13. & 2.3 & -2.52 & 90 & 18 & 172 & 27 & 280 \\
\hline 14. & 2.5 & -4.13 & 70 & 4 & 410 & 14 & 130 \\
\hline Mean \pm S.D. & & $-2.82 \pm 1.59$ & $86 \pm 10$ & $11 \pm 6$ & $240 \pm 109$ & $16 \pm 6$ & $223 \pm 69$ \\
\hline \multicolumn{8}{|l|}{ Group II } \\
\hline 15. & 5.0 & -4.26 & 94 & 6 & 389 & 6 & 210 \\
\hline 16. & 6.3 & -1.94 & 111 & 13 & 318 & 14 & 260 \\
\hline 17. & 6.4 & -3.14 & 103 & 9 & 424 & 29 & 380 \\
\hline 18. & 7.9 & -3.35 & 90 & 7 & 820 & 38 & 182 \\
\hline 19. & 8.6 & -3.38 & 114 & 7 & 569 & 22 & 248 \\
\hline 20. & 9.5 & -3.98 & 94 & 4 & 998 & 42 & 234 \\
\hline 21. & 11.9 & -3.02 & 112 & 11 & 869 & 35 & 175 \\
\hline Mean \pm S.D. & & $-3.30 \pm 0.75$ & $103 \pm 10^{2}$ & $8 \pm 3$ & $627 \pm 268^{3}$ & $27 \pm 13$ & $241 \pm 69$ \\
\hline
\end{tabular}


of $90 \%$ or less and three having values of $80 \%$ or less. Mean weight for height index in Group II was normal (mean 103\%, range 90-114) and significantly greater than for Group I (mean 86\%, range $70-114, P<0.01$ ). There was a significant increase in weight for height index with age throughout childhood $(r=0.62, P<$ 0.005 ). In Group I there was a significant correlation (Table 3) between weight for height index and HSDS, the most growth retarded children being the most underweight for height (wasted). In Group II this correlation was not significant. In Group II, but not Group I, there was a highly significant correlation (Table 3 )

Table 3. Correlation coefficients

\begin{tabular}{lcccc}
\hline & \multicolumn{2}{c}{ Group I } & \multicolumn{2}{c}{ Group II } \\
\cline { 2 - 5 } & $r$ & $P$ & $r$ & $P$ \\
\hline $\begin{array}{l}\text { Height standard deviation score } v s \\
\quad \text { weight for height index }\end{array}$ & 0.67 & $<0.01$ & 0.63 & $\mathrm{NS}^{1}$ \\
$\begin{array}{c}\text { Height standard deviation score } v s \\
\quad \text { serum transferrin }\end{array}$ & 0.67 & $<0.01$ & 0.22 & $\mathrm{NS}$ \\
$\begin{array}{l}\text { Weight for height index vs serum } \\
\quad \text { transferrin }\end{array}$ & 0.72 & $<0.005$ & 0.18 & $\mathrm{NS}$ \\
$\begin{array}{l}\text { Intracellular water O/P vs height } \\
\quad \text { standard deviation score }\end{array}$ & 0.58 & $<0.05$ & 0.55 & $\mathrm{NS}$ \\
$\begin{array}{c}\text { Intracellular water O/P vs weight } \\
\text { for height index }\end{array}$ & 0.40 & $\mathrm{NS}$ & 0.54 & $\mathrm{NS}$ \\
$\begin{array}{l}\text { Intracellular water O/P vs glomer- } \\
\quad \text { ular filtration rate }\end{array}$ & 0.55 & $<0.05$ & 0.66 & $\mathrm{NS}$ \\
$\begin{array}{c}\text { Height standard deviation score } v s \\
\text { glomerular filtration rate }\end{array}$ & 0.33 & $\mathrm{NS}$ & 0.93 & $<0.005$ \\
\hline
\end{tabular}

${ }^{1} \mathrm{NS}$, not significant. between HSDS and GFR, the children with the most marked impairment of renal function being the most growth retarded.

Most children in both groups had serum transferrin levels within the normal range (Table 2), and there was no significant difference between the means for the two groups. The lowest levels, however, were found in Group I, where mean serum transferrin $(223 \pm 69$ S.D. $\mathrm{mg} / \mathrm{dl}$ ) was significantly reduced compared to control children, $(P<0.05)$ and four children had levels more than 2 S.D. below the control mean. In Group I serum transferrin was significantly correlated with both HSDS and weight for height index, the lowest levels being found in the most growth retarded and wasted children; in Group II these correlations were absent (Table 3).

Body composition. Results are shown in Table 4. TBW in Group I was $46-71 \%$ (mean $60 \%$ ) of body weight compared to $55-73 \%$ (mean 64\%) in Group II. When expressed as an O/P ratio, TBW was significantly reduced compared to normal in Group I $(P<$ 0.01 ) but not in Group II, where the mean ratio was marginally but insignificantly raised compared to normal. Mean $O / P$ ratio for TBW was significantly lower in Group I compared to Group II $(P<0.01)$. ECV was $24-35 \%$ (mean $29 \%$ ) of body weight in Group I and 22-29\% (mean 26\%) of body weight in Group II. Mean $\mathrm{O} / \mathrm{P}$ ratios for ECV were not significantly different from normal in either group, although in Group II five out of seven children had values greater than unity. There was no significant difference for ECV O/P ratio between Groups I and II. In neither group was there any significant correlation between ECV $\mathrm{O} / \mathrm{P}$ ratio and either blood urea or GFR.

ICW was $22-39 \%$ (mean $31 \%$ ) of body weight in Group I children and $33-43 \%$ (mean $38 \%$ ) in Group II $(P<0.05)$. ICW $\mathrm{O} / \mathrm{P}$ ratio was significantly reduced compared to normal in Group I $(P<0.01)$ but not in Group II. Mean ICW O/P ratio was

Table 4. Body composition data

\begin{tabular}{|c|c|c|c|c|c|c|c|c|c|}
\hline \multirow{2}{*}{ Case } & \multicolumn{3}{|c|}{ Total body water } & \multicolumn{3}{|c|}{ Extracellular volume } & \multicolumn{3}{|c|}{ Intracellular water } \\
\hline & Litres & $\%$ body weight & $\mathrm{O} / \mathrm{P}$ & Litres & $\%$ body weight & $\mathrm{O} / \mathrm{P}$ & Litres & $\%$ body weight & $\mathrm{O} / \mathrm{P}$ \\
\hline \multicolumn{10}{|l|}{ Group I } \\
\hline 1. & 2.55 & 71 & 0.76 & 1.26 & 35 & 1.21 & 1.29 & 36 & 0.56 \\
\hline 2. & 2.28 & 58 & 0.68 & 0.96 & 24 & 1.01 & 1.32 & 34 & 0.55 \\
\hline 3. & 2.93 & 61 & 0.71 & 1.16 & 24 & 0.75 & 1.77 & 37 & 0.68 \\
\hline 4. & 4.60 & 60 & 0.86 & 2.30 & 30 & 1.01 & 2.30 & 30 & 0.75 \\
\hline 5. & 3.66 & 54 & 0.69 & 1.70 & 25 & 0.74 & 1.96 & 29 & 0.65 \\
\hline 6. & 3.44 & 61 & 0.77 & 1.86 & 33 & 1.11 & 1.58 & 28 & 0.57 \\
\hline 7. & 5.31 & 46 & 0.82 & 2.83 & 24 & 0.99 & 2.48 & 22 & 0.69 \\
\hline 8. & 3.28 & 56 & 0.69 & 1.61 & 27 & 0.87 & 1.67 & 29 & 0.58 \\
\hline 9. & 6.36 & 67 & 0.91 & 2.68 & 28 & 0.89 & 3.68 & 39 & 0.93 \\
\hline 10. & 5.56 & 59 & 0.85 & 3.04 & 32 & 1.09 & 2.52 & 27 & 0.67 \\
\hline 11. & 4.56 & 58 & 0.77 & 2.23 & 28 & 0.87 & 2.33 & 30 & 0.69 \\
\hline 12. & 5.75 & 60 & 0.86 & 2.64 & 28 & 0.97 & 3.11 & 32 & 0.82 \\
\hline 13. & 6.38 & 66 & 0.95 & 3.01 & 31 & 1.17 & 3.37 & 35 & 0.81 \\
\hline 14. & 4.44 & 60 & 0.69 & 2.58 & 35 & 0.95 & 1.86 & 25 & 0.50 \\
\hline Mean \pm S.D. & & $60 \pm 8$ & $0.79 \pm 0.09^{1}$ & & $29 \pm 4$ & $0.97 \pm 0.14$ & & $31 \pm 5$ & $0.67 \pm 0.12^{1}$ \\
\hline \multicolumn{10}{|l|}{ Group II } \\
\hline 15 & 7.00 & 55 & 0.83 & 2.84 & 22 & 0.77 & 4.16 & 33 & 0.88 \\
\hline 16. & 12.96 & 65 & 1.11 & 5.65 & 28 & 1.19 & 7.31 & 37 & 1.04 \\
\hline 17. & 12.65 & 73 & 1.18 & 5.00 & 29 & 1.12 & 7.65 & 44 & 1.23 \\
\hline 18. & 11.10 & 67 & 0.94 & 4.62 & 28 & 0.97 & 6.48 & 39 & 0.92 \\
\hline 19. & 13.38 & 59 & 1.05 & 5.89 & 26 & 1.19 & 7.49 & 33 & 0.95 \\
\hline 20. & 11.60 & 64 & 1.08 & 5.07 & 28 & 1.04 & 6.53 & 36 & 0.89 \\
\hline 21 & 18.29 & 66 & 1.21 & 6.30 & 23 & 1.26 & 11.99 & 43 & 1.20 \\
\hline Mean \pm S.D. & & $64 \pm 6$ & $1.06 \pm 0.13$ & & $26 \pm 3$ & $1.08 \pm 0.17$ & & $38 \pm 4$ & $1.01 \pm 0.14$ \\
\hline Group I & & $\mathrm{NS}^{2}$ & $P<0.01$ & & NS & NS & & $P<0.05$ & $P<0.01$ \\
\hline \multicolumn{10}{|l|}{$\begin{array}{l}\text { vs } \\
\text { Group II }\end{array}$} \\
\hline Group II & & & & & & & & & \\
\hline
\end{tabular}

\footnotetext{
' $P<0.01$ observed values compared to predicted normal.

${ }^{2} \mathrm{NS}$, not significant.
} 
significantly lower in Group I compared to Group II $(P<0.01)$. The relationship between ICW in litres and height for both groups in comparison to that for normal children is shown in Figure 2. The relationship between ICW $\mathrm{O} / \mathrm{P}$ ratio and age is shown in Figure 3. There was a significant increase in this ratio with increasing age throughout childhood $(r=0.79, P<0.001)$. Considering combined data from both groups, there was a highly significant correlation between ICW $\mathrm{O} / \mathrm{P}$ and weight for height index $(r=0.71, P<0.001)$. In Group I there was also a significant correlation between ICW O/P ratio and both HSDS and GFR (Table 3), the children with the greatest reduction in ICW being the most growth retarded and having the most marked impairment of renal function. In Group II these correlations were not significant. In neither group was there any significant correlation between ICW O/P ratio and either ECV O/P ratio or blood urea.

Dietary data. Data available at the time of initial study for 11 children in Group I and seven children in Group II are shown in Figure 4. Mean calorie intake in Group I was 79\% RDA (range 40-116\%) and in Group II 123\% (range 66-185\%). This difference is not statistically significant. All children not on calorie supplements had calorie intakes less than $100 \%$ RDA; in all but one of these children it was less than $80 \%$ RDA. In Group I, children receiving a calorie supplement had a significantly greater calorie intake than those not receiving a supplement (mean 92 versus 57\%, $P<0.05$ ), but many of the former still had calorie intakes below RDA. Protein intake was 91\% MRP (range 56-117\%) in Group I and 158\% (range 104-230\%) in Group II. This difference is not statistically significant. Eight children in Group I, but none in Group II, had protein intakes less than minimum requirement for protein (MRP) for height age. There were no significant correlations in either Group I or II between either calorie or protein intakes and HSDS, \% weight for height index, serum transferrin, or body composition.

Repeat studies. (Table 5 and Fig. 3) Repeat estimations of HSDS, \% weight for height index, serum transferrin, and ICW were obtained in seven Group I children after an interval of 0.8 years in 6 cases, and 0.4 years in one case. Between studies, a free diet was eaten with a calorie supplement in two children (cases 8

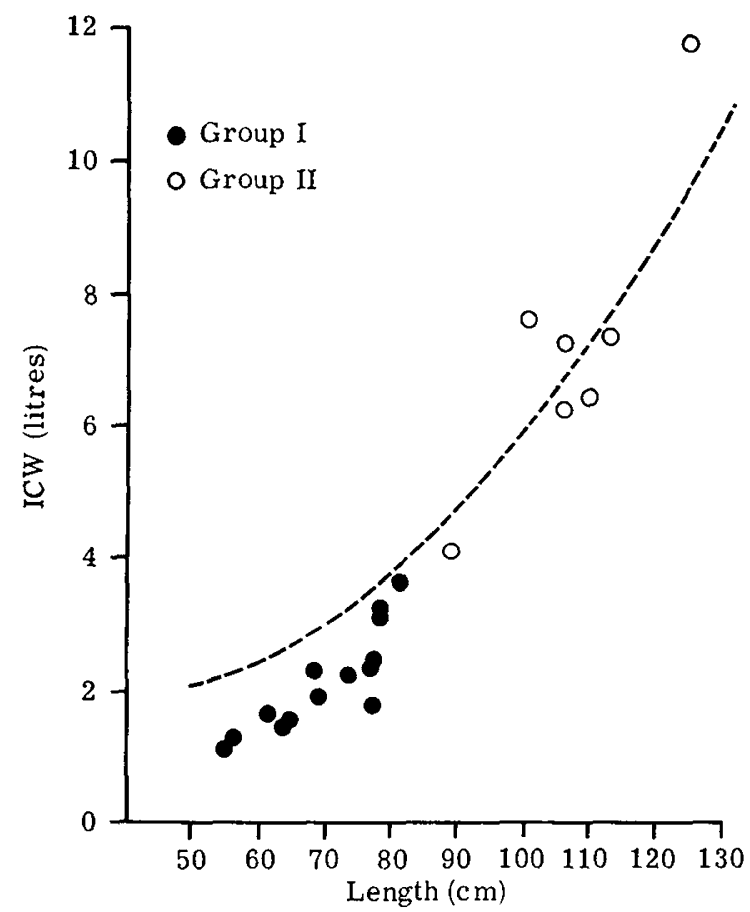

Fig. 2. Intracellular water, ICW, values plotted against length (or height). The interrupted line shows mean ICW for normal children calculated from the formula: $\mathrm{ICW}=3.0705-0.0674 \mathrm{ht}+0.00098 \mathrm{ht}^{2}$ (13).

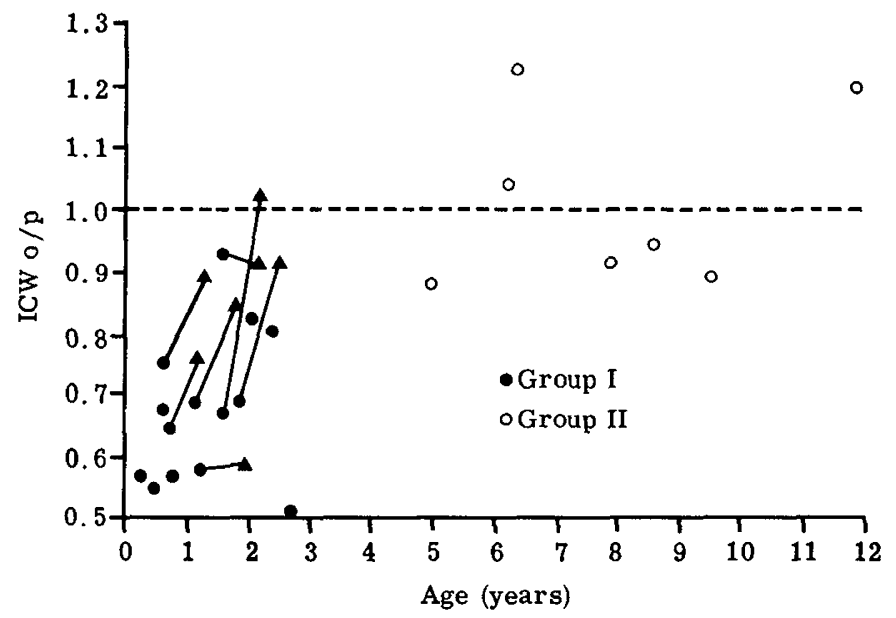

Fig. 3. Intracellular water, ICW, expressed as a ratio of observed:predicted $(\mathrm{O} / \mathrm{P})$, plotted against age. Repeat studies in six Group I children are shown $(-\Delta)$. The increase in $\mathrm{ICW} \mathrm{O} / \mathrm{P}$ ratio towards unity (as shown by the broken line) through early childhood is evident.

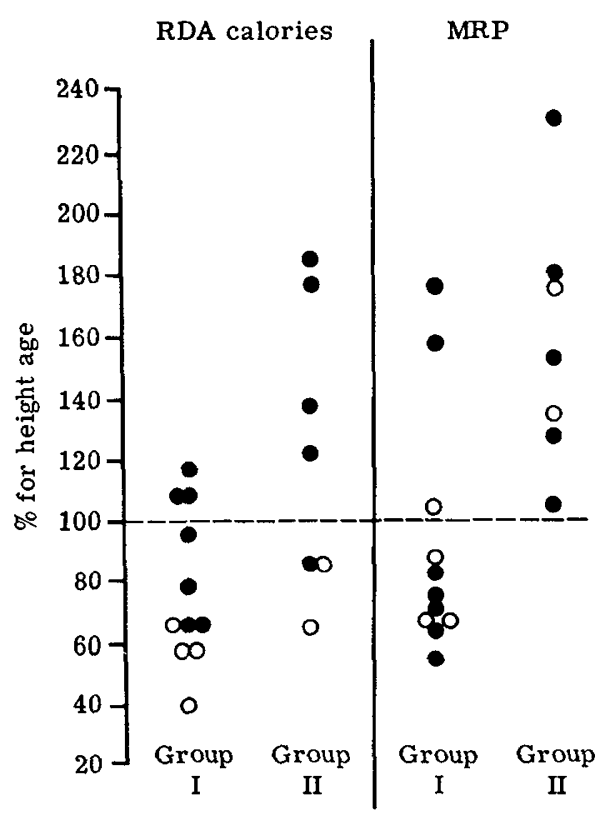

Fig. 4. Calorie (left hand column) and protein (right hand column) intakes in 18 children in relation to height age. Closed circles show intakes for children receiving a calorie supplement, open circles for those not receiving a calorie supplement.

and 11). Dietary records were available in only five children. Mean calorie intake was $77 \%$ RDA (range 64-98\%) and mean protein intake was $187 \%$ MRP (range 128-326\%). These intakes did not differ significantly from those recorded before the initial studies. Between studies there was no significant change in mean HSDS, weight for height index, plasma creatinine, or serum transferrin. There was a significant negative correlation between initial HSDS and subsequent change in HSDS, the most growth retarded children initially showing the best growth between studies $(r=-0.77, P<0.05)$. ICW, expressed in litres, increased in all children between studies. ICW O/P ratio increased in six children as shown in Figure 3. The mean change in $\mathrm{ICW} O / \mathrm{P}$ ratio was statistically significant $(P=0.05)$. There was no significant correlation between dietary intakes for calories or protein, and change in either HSDS, weight for height index, serum transferrin or $I C W O / P$ ratio. Change in $I C W O / P$ ratio did not correlate significantly with change in HSDS, weight for height index, or serum transferrin. 
Table 5. Longitudinal data in Group I

\begin{tabular}{|c|c|c|c|c|c|c|c|}
\hline \multirow{2}{*}{ Case } & \multirow{2}{*}{$\begin{array}{l}\text { Interval between } \\
\text { studies (yr) }\end{array}$} & \multicolumn{2}{|c|}{ Dietary data } & \multicolumn{4}{|c|}{ Change between studies in } \\
\hline & & $\begin{array}{c}\text { Cals \%RDA } \\
\text { height age }\end{array}$ & $\begin{array}{c}\text { Prot \%MRP } \\
\text { height age }\end{array}$ & $\begin{array}{l}\text { Height standard } \\
\text { deviation score }\end{array}$ & $\begin{array}{l}\text { Weight for height } \\
\text { index }\end{array}$ & Serum transferrin & $\begin{array}{c}\text { Intracellular } \\
\text { water } \mathrm{O} / \mathrm{P}\end{array}$ \\
\hline 4. & 0.8 & 98 & 326 & -0.3 & -1 & +25 & +0.14 \\
\hline 5. & 0.8 & 68 & 128 & -0.7 & -5 & +20 & +0.10 \\
\hline 7. & 0.8 & 73 & 141 & -0.9 & -24 & -45 & +0.15 \\
\hline 8. & 0.8 & 84 & 190 & +1.4 & -18 & +50 & +0.01 \\
\hline 9. & 0.8 & $\mathrm{NA}^{3}$ & $\mathrm{NA}$ & +0.8 & +3 & +47 & -0.03 \\
\hline 10 & 0.4 & NA & NA & -0.1 & +2 & -8 & +0.36 \\
\hline 11. & 0.8 & 64 & 150 & +0.5 & 0 & +33 & +0.24 \\
\hline Mean & & 77 & 187 & +0.1 & -6 & +17 & $+0.14^{2}$ \\
\hline
\end{tabular}

' NA, not available.

${ }^{2} P=0.05$.

\section{DISCUSSION}

An increasing number of children with early onset CRF due to congenital renal disease are now accepted for dialysis and transplantation, and survive into adolescence and adult life, often with marked height deficit. Unfortunately, only data on weight rather than length at birth were available for children in the present study; however, extrapolating from the cross sectional data shown in Figure 1 it seems likely that their growth pattern was similar to that described by Betts and Magrath (2), initial poor growth in infancy with a falling away from normal height centiles and, often, clinical presentation with failure to thrive, being followed by growth at a normal, or near normal, rate during the rest of childhood. The crucial contribution to final height of early poor growth, and the difficulty in achieving subsequent catch-up growth either on conservative treatment for CRF, or after the institution of regular dialysis, have been repeatedly emphasised $(2,26,33)$. The data presented here, although circumstantial, lend support to the suggestion $(2,33)$ that poor nutrition is a major factor contributing to this early poor growth, and that adaptive mechanisms in uraemic children may limit both longterm disturbances of their body composition and also, perhaps, their potential for catch-up growth.

Intracellular water reflects body cell mass, and studies by Cheek et al. (13) using methodology similar to that described here have emphasised both its close relationship to height in normal children, and also its use as a measure of body protein stores in disease states such as PCM. In uraemic subjects, however, it is pertinent to consider critically the accuracy of ICW estimated as TBW minus corrected sodium bromide space. Although the latter is the preferred method of ECV estimation in normal subjects (11), its measurement is relatively imprecise, and abnormal cell membrane permeability to small molecules in uraemia (28) might lead to an overestimate of ECV by bromide and a corresponding underestimate of ICW; however, studies of electrolyte distribution in uraemic adults by Brennan et al. (6) suggest that the increased bromide space reflects a genuine increase in ECV. These investigators have also shown a close correlation in uraemic subjects between ICW calculated from TBW minus corrected sodium bromide space and TBK similar to that previously described in normals (36). A similar correlation between total exchangeable potassium and ICW has also been found in normal and uraemic adults when sulphate space has been used as an estimate of ECV (39). We have found ( $R$. Jones, unpublished data) no difference between the extent to which the sodium bromide space overestimates the volume of distribution of $\left[{ }^{51} \mathrm{Cr}\right]-E D T A$ in uraemic patients on regular dialysis compared with that in normal adults, suggesting that increased intracellular passage of bromide in uraemia, at least compared with $\left[{ }^{51} \mathrm{Cr}\right]$-EDTA, is unlikely. In the present study there was no correlation between ICW reduction and ECV expansion as would be expected if the former reflected overestimation of ECV by bromide, and no significant correlation between either blood urea or GFR (as markers of uraemic toxicity) and degree of ECV expansion. Indeed, some children, particularly in Group I, had a reduction of ECV compared to predicted values suggesting that, despite salt supplements, some had a degree of ECV contraction. In view of the generally accepted accuracy of tritium for the estimation of TBW, overall these considerations support the validity of our methodology for ICW estimation.

To our knowledge, studies of body composition in infants and young children with CRF have not previously been reported. In adults with CRF, Coles (14) and Comty (15) found a reduction in ICW compared to predicted values, with increased TBW largely due to ECV expansion. Similar findings in children with PCM were reported by Alleyne (1) and Cheek et al. (I3). Increased TBW and ECV were also found in five out of the seven children in Group II of the present study, although the mean variations from normal in this small group were not statistically significant (Table 4). In a previous study of older children and adolescents on regular dialysis (19), we found increased TBW and ECV, with reduced ICW relative to height in prepubertal children, but normal ICW in pubertal children. Total body potassium, an alternative index of body cell mass, correlates with ICW in uraemia as in health $(6,36,39)$ and may be normal $(5,6,30)$ or reduced $(39)$ in adults with CRF on conservative treatment or dialysis. In children and adolescents of undetermined pubertal status with CRF on conservative treatment, Weber et al. (43) found TBK to be reduced by a mean of $17 \%$ compared to predicted values. In this study, however, none of the children had an onset of CRF below 2 years of age, and the youngest was 4.5 years old at the time of study. In the present report infants and children under 3 years of age with early onset CRF had normal ECV, with reduced TBW due to marked reduction in ICW. The latter suggests loss of body cell mass, and is similar to the findings in malnourished Peruvian and Guatemalan children reported by Cheek et al. (13), who used similar body composition methodology, and the same formula for predicted ICW values. This study also showed increased ICW values in rehabilitated children similar to the increases found in the seven Group I children (Fig. 2) in whom repeat ICW estimations were available. In our study the most marked reductions in ICW in Group I were found in the most growth retarded children (Table 3). Because non-nutritional factors stunting growth in children with CRF, such as renal osteodystrophy would most likely lead to preservation of ICW relative to height, these results suggest that poor nutrition, and subsequent depletion of body protein at a time when normal children are growing most rapidly, are a cause rather than the result of their poor growth.

In children with PCM it has been suggested (13) that reduction in ICW relative to height reflects dietary protein rather than calorie deficiency. In CRF, malnutrition reflects not only decreased nutrient intake, but also the effects on protein metabolism of complex hormonal and metabolic abnormalities arising from the uraemic state $(24,27)$. In the uraemic rat, there is evidence that requirements for growth of both protein and calories may be increased $(10,34)$, and the importance of considering both calorie and protein intakes as closely dependent determinants of nitrogen balance (and therefore body protein stores) in uraemic patients has been recently emphasised by Munro (38). In the present study 
(Fig. 4), all children not on calorie supplements, and some of those receiving supplements, had calorie intakes less than those recommended for normal children of the same height (recommended daily allowance for height age), and in many cases they were less than $80 \%$ recommended daily allowance for height age, the intake below which growth velocity has previously been found to be reduced in children with CRF $(2,23)$. Although the spontaneous protein intakes of children with CRF in both the present and previous studies have often been adequate for height age, some children in Group I had intakes below MRP, often in the face of an inadequate calorie intake. Therefore, although depleted body protein in most infants and children with CRF probably reflects abnormal protein metabolism $(24,27)$ in combination with a deficient dietary intake of calories rather than protein, the latter may also be contributory in some cases.

As a guide to nutritional status, weight for height index reflects wasting, is independent of age, and preferable to weight for age which takes no account of stunting (45). In Group I of the present study 10 children had values of $90 \%$ or less, and three of $80 \%$ or less, indicating mild and moderate malnutrition respectively according to the classification for children with PCM of Waterlow (45). In Group II weight for height index was $90 \%$ or more in all children. Similar differences with age are evident from the data of West and Smith (46), who used this index as evidence of calorie deficiency in a study which included 17 children with growth retardation due to CRF dating from infancy. Weight for height was $90 \%$ or less in four out of five children under 3 years of age, but in only one of 12 children over 3 years. In this study, as in ours, analysis of the data reveals a significant increase in weight for height index with increasing age throughout childhood $(r=$ $0.56, P<0.02$ ). A significant correlation between weight for height index and ICW $\mathrm{O} / \mathrm{P}$ would be expected, and was present for combined data from Groups I and II in the present study. The lack of correlation between these variables in Group I probably reflects the narrow range of weight for height index in this group. Alternatively, some children had reduction in ICW $\mathrm{O} / \mathrm{P}$ without reduction in weight for height index suggesting preservation or increase in body fat. Increased total body fat has been previously documented in some adults and children with CRF $(15,19)$, and would tend to obscure the effects of depleted body cell mass on body weight, and therefore weight for height index. Serum transferrin has also been used as an index of nutritional status in both PCM (32) and CRF (47), and was closely correlated with weight for height index in Group I of our study (Table 3). Although within the normal range in most cases, mean levels were significantly reduced in Group I children, in whom serum transferrin was correlated significantly with HSDS. There was also a close correlation between HSDS and weight for height index, the most growth retarded children in Group I being the most wasted (Table 3 ). These correlations further support the contention that nutritional factors are important determinants of height deficit in these children. They were not significant in Group II, where there was however a correlation between HSDS and GFR. Betts and Magrath (2) have previously found that growth velocity in children with CRF is reduced below normal when GFR falls below $25 \mathrm{ml} /$ $\min / 1.73 \mathrm{~m}^{2}$; however, a correlation between degree of renal impairment and stunting (rather than reduction in growth velocity) has not previously been demonstrated and was a surprising finding. In view of the small number of children in Group II, this strong correlation may be fortuitous. Alternatively, it may reflect the longterm effects on growth of variable degrees of impaired renal function which have remained stable (as is common in children with congenital renal hypoplasia) over many years.

A striking feature of the present study was the contrast between Group I children, who showed evidence of malnutrition and depleted body protein, and Group II children who had normal body weight and ICW in relation to height. There was a highly significant correlation between increasing age and both weight for height index and ICW $\mathrm{O} / \mathrm{P}$ ratio. Longitudinal studies in seven Group I children showed a significant increase in ICW relative to height over a period during which growth was generally poor, although this was more adequate in those children most growth retarded initially. A similar correlation between initial degree of growth retardation and subsequent growth performance has also been noted in children starting regular haemodialysis (26). Between our studies no special nutritional therapy was given; indeed the limited dietary data available suggested that, in some cases, increase in ICW had occurred in the face of a deficient dietary intake of calories. These findings are suggestive of metabolic adaptation to a decreased nutrient intake in children with onset of CRF in infancy, similar to that found in children with PCM (44). The latter have been shown to maintain positive nitrogen balance, and thereby preserve body protein stores, on a diet which, in the rehabilitated child, is deficient and results in loss of body nitrogen (21). A reduction in whole body protein turnover is probably one means by which this adaptation occurs in PCM $(21,44)$, and has also been documented in children with CRF by Conley et al. (16). This study concluded that the low protein turnover rates of uraemic children on conservative treatment reflected their decreased calorie and protein intakes, and that a reduction of azotaemia by regular haemodialysis improved, but did not normalise, turnover at any given energy intake. Small size in both PCM and CRF might also be adaptive by reducing the demand for nutrients and, in CRF, thereby limiting the intake of potentially toxic substances such as nitrogen and phosphate. Our study is consistent with the hypothesis that poor growth in early life in children with CRF may, together with metabolic adaptation, allow normalisation of body cell mass and body weight in relation to height during the period of maximum growth velocity for normal children. Perhaps growth at a normal rate then becomes possible as is suggested by their subsequent growth pattern (2); however, this state of adaptation might also limit the effectiveness with which nutritional therapy can promote supranormal or catch-up growth later in childhood. Final height in children with CRF will ultimately depend on the extent to which skeletal maturation is delayed in relation to retarded linear growth. No data on skeletal maturation for children in the present study are considered here; however, although slowed skeletal maturation may initially limit loss of growth potential, Betts and White (3) have emphasised that with increasing age there is progressive retardation of height age relative to bone age resulting in progressive loss of growth potential. It therefore follows that the early diagnosis of CRF, and the promotion of optimum growth in infants and young children with CRF, is likely to be the most effective way of improving final height. Our study suggests that, in the absence of renal transplantation and a return to normal renal function, the provision of nutritional therapy to maintain body protein stores in early childhood is one means whereby this improvement might best be achieved.

\section{REFERENCES AND NOTES}

1. Alleyne, G. A.: Studies on total body potassium in infantile malnutrition: the relation to body fluid spaces and urinary creatinine. Clin. Sci., 34: 199 (1968).

2. Betts, P. R. and Magrath, G.: Growth pattern and dietary intake of children with chronic renal insufficiency. Br. Med. J., 2: 189 (1974).

3. Betts, P. R. and White, R. H. R.: Growth potential and skeletal maturity in children with chronic renal insufficiency. Nephron, 16: 325 (1976).

4. Bianchi, R., Mariani, G., Toni, M. G. and Carmassi, F.: The metabolism of human serum albumin in renal failure on conservative and dialysis therapy. Am. J. Clin. Nutr., 31: 1615 (1978).

5. Boddy, K., King, P. S., Lindsay, R. M., Briggs, J. D., Winchester, J. F., and Kennedy, A. C.: Total body potassium in non-dialysed and dialysed patients with chronic renal failure. Br. Med. J., I: 771 (1972).

6. Brennan, B. L., Yasumura, S., Letteri, J. M., and Cohn, S. H.: Total body electrolyte composition and distribution of body water in uraemia. Kidney Int., 17: 364 (1980).

7. Broyer, M., Jean, G., Dartois, A., and Kleinknecht, C.: Plasma and muscle free amino acids in children at the early stages of renal failure. Am. J. Clin. Nutr., 33: 1396 (1980)

8. Chantler, C. and Barratt, T. M.: Estimation of glomerular filtration rate from plasma clearance of 51-chromium edetic acid. Arch. Dis. Child., 47: 613 (1972).

9. Chantler, C. and Holliday, M. A.: Growth in children with renal disease with particular reference to the effects of calorie malnutrition: a review. Clin. Nephrol., 1: 238 (1973).

10. Chantler, C., Lieberman, E., and Holliday, M. A.: A rat model for the study of 
growth failure in uraemia. Pediatr. Res., 8: 109 (1974).

11. Cheek, D. B.: Extracellular volume-its structure, measurement and the influence of age and disease. J. Pediatr., 58: 103 (1961).

12. Cheek, D. B. and Talbert, J. L.: Extracellular volume (and sodium) and body water in infants. In: D. B. Cheek, Human Growth, Body Composition, Cell Growth, Energy and Intelligence. p. 117-134 (Lea and Febiger, Philadelphia, PA, 1968).

13. Cheek, D. B., Habicht, J. P., Berall, J., and Hold, A. B.: Protein-calorie malnutrition and the significance of cell mass relative to body length. Am. J. Clin. Nutr., 30: 851 (1977).

14. Coles, G. A.: Body composition in chronic renal failure. Q. J. Med., 41: 25 (1972).

15. Comty, C. M.: A longitudinal study of body composition in terminal uraemics treated by regular haemodialysis. Can. Med. Ass. J., 98: 482 (1968).

16. Conley, S. B., Rose, G. M., Robson, A. M., and Bier, D. M.: Effects of dietary intake and haemodialysis on protein turnover in uraemic children. Kidney Int., 17: 837 (1980).

17. Delaporte, C., Bergstrom, J., and Broyer, M.: Variations in muscle cell protein of severely uraemic children. Kidney Int., 10: 239 (1976).

18. Department of Health and Social Security: Recommended daily amounts of food, energy and nutrients for groups of people in the U.K. Her Majesty's Stationery Office, London, (1979).

19. El Bishti, M., Burke, J., Gill, D., Jones, R. W., Counahan, R., and Chantler, C.: Body composition in children on regular hemodialysis. Clin. Nephrol., 15: 53 (1981).

20. Gilli, G., Mehls, O., Fischer, W., and Scharer, K.: Final height of children with chronic renal failure. Pediatr. Res. (abstr.), 14: 1015 (1980).

21. Golden, M. H. N., Waterlow, J. C., and Picou, D.: Protein turnover, synthesis and breakdown before and after recovery from protein-energy malnutrition. Clin. Sci. Mol. Med., 53: 473 (1977).

22. Holliday, M. A., Chantler, C., MacDonnel, R., and Keitges, J.: Effect of uraemia on nutritionally-induced variations in protein metabolism. Kidney Int., 11:236 (1977).

23. Holliday, M. A.: Calorie deficiency in children with uraemia: effect upon growth. Pediatrics, 50: 590 (1972).

24. Holliday, M. A. and Chantler, C.: Metabolic and nutritional factors in children with renal insufficiency. Kidney Int., 14: 306 (1978).

25. Kaufmann, L. and Wilson, C.: Determination of extracellular fluid volume by fluorescent excitation analysis of bromine. J. Nucl. Med., 14: 812 (1973).

26. Kleinknecht, C., Broyer, M., Gagnadoux, M., Martihenneberg, C., Dartois, A., Kermanach, C., Pouliquen, M., Degoulet, P., Usberti, M., and Roy, M.: Growth in children treated with long-term dialysis. A study of 76 patients. In: M. H. Maxwell, Advances in Nephrology. p. 133-163 (Year Book Medical Publishers Inc., 1980).

27. Kopple, J. D.: Abnormal amino acid and protein metabolism in uraemia. Kidney Int., 14: 340 (1978).

28. Kramer, H. J., Gospodinov, D., and Kruck, F.: Functional and metabolic studies on red blood cell sodium transport in chronic uraemia. Nephron, 16: 344 (1975).

29. Langham, W. H., Eversole, W. J., Hayes, F. N., Trujillo, T. T., Los Alamos, N. M.: Assay of tritium activity in body fluids with the use of liquid scintillation system. J. Lab. Clin. Med., 47: 819 (1956).

30. Letteri, J. M., Ellis, K. J., Asad. S. N., and Cohn, S. H.: Serial measurement of total body potassium in chronic renal disease. Am. J. Clin. Nutr., 31: 1937 (1978).

31. McCance, R. A and Widdowson, E. M. The composition of foods. Special Report Series No. 297. Her Majesty's Stationery Office, London, (1969).

32. McFarlane, H., Ogbeide, M. I., Reddy, S., Adcock, K. J., Adeshina, H., Gurney, J. M., Cooke, A., Taylor, G. O., Mordie, J. A.: Biochemical assessment of protein calorie malnutrition. Lancet, $l: 393$ (1969).

33. Mehls, O., Ritz, E., Gilli, G., and Kreusser, W.: Growth in renal failure. Nephron, 21: 237 (1978)

34. Mehls, O., Ritz, E., Gilli, G., Bartholome, K., Beisbarth, H., Hohenegger, M. and Schafnitzel, W.: Nitrogen metabolism and growth in experimental uremia. Int. J. Pediatr. Nephrol., 1: 34 (1980).

35. Mellitz, E. D. and Cheek, D. B.: Growth and body water. In: D. B. Cheek Human Growth, Body Composition, Cell Growth and Intelligence. p. 135-149, (Lea and Febiger, Philadelphia, 1968).

36. Moore, F. D.: In: Moore, F. D. The body cell mass and its supporting environment. p. 146 (W. H. Saunders Company, Philadelphia, 1963).

37. Moss, G.: Scintillation counting of plasma tritiated water. J. Lab. Clin. Med., 63. 315 (1964).

38. Munro, H. M.: Energy and protein intakes as determinants of nitrogen balance Kidney Int., 14: 313 (1978).

39. Rettori, V., Gral, T., Massry, S. G., and Villamil, M. F.: Exchangeable potassium content and distribution in normal subjects and uraemic patients on chronic haemodialysis. Clin. Sci., 42 : 673 (1972).

40. Schwartz, G. J., Haycock, G. B., Edelmann, C. M., and Spitzer, A.: A simple estimate of glomerular filtration rate in children derived from body length and plasma creatinine. Pediatrics, 58: 259 (1976).

41. Thomson, A. M., Billewicz, W. Z, and Hytten, F. E. The assessment of fetal growth. J. Obstet. Gynaecol. Br. Common., 75: 905 (1968).

42. Tanner, J. M., Whitehouse, R. H., and Takashi, M.: Standards from birth to maturity for height, weight, height velocity and weight velocity: british children. Arch. Dis. Child. 41: 613 (1966).

43. Weber, H. P., Michalk, D., Rauh, W., Romahn, A., and Scharer, K.: Total body potassium in children with chronic renal failure. Int. J. Pediatr. Nephrol., $1: 42$ (1980).

44. Waterlow, J. C.: Observations on the mechanism of adaptation to low protein diets. Lancet, 2: 1091 (1968).

45. Waterlow, J. C.: Classification and definition of protein energy malnutrition. In G. H. Beaton and J. M. Bergon. Nutrition in Preventive Medicine. p. 530-555 (W. H. O., Geneva. 1976).

46. West, C. D. and Smith, W. C.: An attempt to elucidate the cause of growth retardation in renal disease. Am. J. Dis. Child., $91: 460$ (1956).

47. Young, G. A., Keogh, J. B., and Parsons, F. M.: Plasma amino acids and protein levels in chronic renal failure and changes caused by oral supplements of essential amino acids. Clin. Chim. Acta., 61: 205 (1975).

48. The authors wish to thank Miss K. M. Start and Miss P. M. Timbrall for the provision of dietary data, and Mr. R. N. Dalton for technical assistance.

49. Requests for reprints should be addressed to: Dr. R. W. A. Jones, Department of Paediatrics, Guy's Hospital, St Thomas Street, London SEl 9RT, UK.

50. This research was supported by grants from the British Kidney Patient Association and the National Kidney Research Fund.

51. Received for publication September 3, 1981.

52. Accepted for publication March 2, 1982. 